\title{
Witold Kwasnicki
}

University of Wrocław

e-mail: witold.kwasnicki@uwr.edu.pl

ORCID: 0000-0002-8739-4991

\section{LEGACY OF LUDWIG VON MISES: RATIONALISM}

\begin{abstract}
There are three intentions (aims) of this paper. First, to focus the attention of readers to three not so well known and least frequently quoted by economists of Mises's books, namely his 1957 Theory and History: An Interpretation of Social and Economic Evolution, and two closely related The Ultimate Foundation of Economic Science: An Essay on Method (1962), and Epistemological Problems of Economics (1933/1960).

The second aim is to outline Mises's legacy, presented in the form of eleven dimensions of Mises's Intellectual Universe. The eleven dimensions of Mises's system are: Economics as science, praxeology, and human action; Methodological dualism; Judgments of value and subjectivism; Individualism; Rationalism and human action; Consumer; Cooperation and competition; Thymology; Mathematics in economics; Predictions; and Historical analysis.

Third, to present the main issues related to Mises's concept of rationalism. There is no mention of Ludwig von Mises's concept of rationality in a great number of books and papers dealing with the understanding of the rationality of human beings. The concept of rationality proposed by Ludwig von Mises is neglected by modern researchers and economists of different schools, but especially by mainstream economists. A good example of neglecting Mises's ideas on rationality is the latest book by Nassim Taleb, Skin in the Game: Hidden Asymmetries in Daily Life. Although Taleb's proposition of understanding rationality and irrationality is very close to the concept of Mises, he does not refer to Mises's work at all. No single word on Mises in that book!

Keywords: rationality, praxeology, mainstream economics, Ludwig von Mises, Austrian school of economics
\end{abstract}

Usually when we think about the legacy of Ludwig von Mises we start from his magnum opus, 'Human Action: A Treatise on Economics' (published in 1949). Next, we think about his famous paper (which initiated probably the most important debate of economists in the $20^{\text {th }}$ century, the so called 'Economic Calculation Debate') 'Die Wirtschaftsrechnung im sozialistischen Gemeinwesen' (1920). That paper was followed by the book published two years later on Die Gemeinwirtschaft: Untersuchungen über 
den Sozialismus (1922, English translation was published in 1951 as Socialism: An Economic and Sociological Analysis). The book which also belongs to the canon of Mises's legacy is Theorie des Geldes und der Umlaufsmittel (1912), published in English in 1953 as Theory of Money and Credit (1953). There are a number of popular and most read books like Liberalismus (1927, published in English as Liberalism or The Free and Prosperous Commonwealth (1962)), Omnipotent Government: The Rise of Total State and Total War (1944), Bureaucracy (1944), Planned Chaos (1947), The Anti Capitalistic Mentality (1956).

However, there are three other of Mises's books, not so well known, and least frequently quoted by economists, which ought to be studied by professional economists. First of all, I am thinking about the 1957 Theory and History: An Interpretation of Social and Economic Evolution ${ }^{1}$, and two closely related The Ultimate Foundation of Economic Science: An Essay on Method (1962), as well as Grundprobleme der Nationalökonomie: Untersuchungen über Verfahren, Aufgaben und Inhalt der Wirtschafts und Gesellschaftslehre (1933, published in English in 1960 as Epistemological Problems of Economics).

I do not claim that Theory and History, The Ultimate Foundation of Economic Sciences, and Epistemological Problems of Economics ought to be read by general readers or be the subject of university courses. I only argue that the reading of these books ought to be obligatory for professional economists $^{2}$. I am convinced that knowledge of Mises's ideas on the role of history in economic analysis, as well as of his philosophical, methodological, and epistemological ideas, can help economists to a better understanding of economic phenomena, shape their thinking, and might be a first step to incorporating the Austrian school into mainstream economics.

I think that even those economists who oppose Mises's ideas, after reading these three books might behave in a similar way as his great opponent, Oskar Lange ('On the Economic Theory of Socialism', The Review of Economic Studies $(1936,1937)$ who just begins the first part of his paper (1936) with expressing thanks to Mises for the challenge posed and the proposal to erect a monument: "Socialists have certainly good reason to be grateful to Professor Mises, the great advocatus diaboli of their cause. For it was his powerful challenge that forced the socialists to recognise the importance of an adequate system of economic accounting to guide the allocation of resources in a socialist economy. Even more, it was chiefly due to Professor Mises's challenge that many socialists became aware of the very existence of such a problem. ... Both as an expression of recognition for the great service rendered by him and as a memento of the prime importance of 
sound economic accounting, a statue of Professor Mises ought to occupy an honourable place in the great hall of the Ministry of Socialisation or of the Central Planning Board of the socialist state. However, I am afraid that Professor Mises would scarcely enjoy what seems the only adequate way to repay the debt of recognition incurred by the socialists, and it is difficult to blame him for not doing so."

The second part of his considerations is summarized by Lange (1937) with this estimate of Mises: "Professor Mises's challenge has had the great merit of having induced the socialists to look for a more satisfactory solution of the problem, and it is only too true that many of them became aware of its very existence only after this challenge. But, as we have seen, those of the socialists who did not or do not realise the necessity and importance of an adequate price system and economic accountancy in the socialist economy are backward not only with regard to the present state of economic analysis: they do not even reach up to the great heritage of Marxian doctrine."

In his publications, Mises convincingly argues that economics (being the most advanced within the general social sciences) is the best-developed part of praxeology, with unique logical and epistemological nature. The economic analysis relies on insights about certain structural features of human action, and that human beings make choices, self-chosen means to attain self-chosen ends (human beings make choices, and that they use means to attain ends). The praxeological character of economics is visible not with empirical investigations but rather postulates that formulated economic laws have a priori character which cannot be confirmed or refuted by the methods predominant in the natural sciences (especially physics). Economic laws and findings exist independent of the particular conditions of time and place, and economists come to know them through pure deductive reasoning. For Mises, economics is not an empirical science in the sense in which the term "empirical" was used by the academic philosophers. Therefore economics ought to be called an aprioristic science.

Although Mises's interest in epistemological problems can be noticed much earlier, namely in the 30s of the $20^{\text {th }}$ century (Mises, 2003/1933), the revival and blossoming of his work on epistemological problems of praxeology was after the publication of Human Action in 1949. Those efforts culminated in the publications of two mentioned books, namely Theory and History (1957), and The Ultimate Foundation of Economic Science (1962).

I fully agree with the opinion of Murray Rothbard that Theory and History is Mises's most neglected book (see Rothbard's review published in 1975 and the preface to the 1985 edition of Theory and History). Rothbard writes: “... Theory and History is more than useful; it is one of Mises's 
greatest works, and indeed one of the great works in this century on the philosophy and methodology of the social sciences. Its neglect is no less than an intellectual tragedy. ... Adherents of the Austrian school of economics have been accused of being antiempirical, mystical a priorists, divorced from economic reality. But a thorough reading of Theory and History reveals quite the opposite; it is the Misesians - the Austrians - who have proper respect for the unique, empirical events of human history, whereas it is the pretentious quantitative "economic scientists" who necessarily abuse and distort the rich empirical facts of history in order to arrive at their allegedly "scientific" quantitative 'laws' and (invariably wrong) forecasts of the future." (Rothbardt, 1975). In a similar mood he writes in the Preface to Theory and History (Mises, 1985): "Mises's fourth and last great work, Theory and History (1957), has made remarkably little impact, and has rarely been cited even by the young economists of the recent Austrian revival. It remains by far the most neglected masterwork of Mises. And yet it provides the philosophical backstop and elaboration of the philosophy underlying Human Action. It is Mises's great methodological work, explaining the basis of his approach to economics, and providing scintillating critiques of such fallacious alternatives as historicism, scientism, and Marxian dialectical materialism. ... Austrian economics will never enjoy a genuine renaissance until economists read and absorb the vital lessons of this unfortunately neglected work. Without praxeology no economics can be truly Austrian or truly sound".

\section{Mises's legacy: 11 dimensions of Mises's Intellectual Universe}

The contribution of Ludwig von Mises to the development of social sciences, praxeology and economics in particular, is impossible to overestimate. His efforts for better understanding of methodological individualism, the role of purposeful action, rationality in human behavior, the law of causality in human action, human cooperation under the division of labor and specialization, etc. give us enormous study material. His books, papers, speeches, and lectures allow us to grasp the refinement and enormously complex philosophical differences involved in the simple idea that "[m]en do not react in ... a uniform way; they behave, as both praxeologists and historians say, in an individual way". (Mises, 1985 (1957), p. 92).

I think that we can distinguish eleven dimensions of Mises's system, which can be estimated as his most significant legacy in economic analysis, namely: Economics as science, praxeology, and human action; Methodologi- 
cal dualism; Judgments of value and subjectivism; Individualism; Rationalism and human action; Consumer; Cooperation and competition; Thymology; Mathematics in economics; Predictions; and Historical analysis.

I am not able to describe, or even outline, all those dimensions in this short paper. In the next section, I will focus only on one of those dimensions related to the proper perception of rationality. Below I present only a concise summary of all eleven dimensions of Mises's system of economic analysis, using some of Mises's original sentences.

1. Economics as science, praxeology, and human action (Economics as a science of human action is a branch of praxeology, the aprioristic theory of human action which is based on theoretical and methodological thinking similar to that of the logician or the mathematician; economists are dealing with human action as distinguished from the natural sciences. The sciences of human action start from the fact that man purposefully aims at ends he has chosen. Although economics (Austrian economics) is frequently called a 'psychological school' it is worth underlining that economics is distinguished from psychology by the fact that it considers action alone and that the psychic events that have led to an action are without importance for it. The starting point of praxeology is a self-evident truth, related to the cognition of action, that there is such a thing as consciously aiming at ends. The natural sciences are causality research; the sciences of human action are teleological. The purpose to which the sciences of human action refer are the ends sought by acting men in the pursuit of their own designs. Human action is entirely determined by the individuals' physiological equipment and by all the ideas working in their minds. The action is purposive conduct. It is not simply behavior, but behavior begot by judgments of value, aiming at a definite end and guided by ideas concerning the suitability or unsuitability of applying (using) definite means. In dealing with human action, we search after the ends the actor wants or wanted to attain and after the result that his action brought about or will bring about. Praxeology abstracts from the concrete content of the ends men are aiming at. There is action and there is the absence of action, but there is nothing in between. Every action is an attempt to exchange one state of affairs for another. To choose is to pick one out of two or more possible modes of conduct and to set aside the alternatives. In the strict sense of the term, the acting man aims only at one ultimate end, at the attainment of a state of affairs that suits him better than the alternatives.)

2. Methodological dualism ('Methodological Dualism' refrains from any proposition concerning essences and metaphysical constructs. It merely takes into account the fact that we do not know how external events - 


\section{Witold Kwasnicki}

physical, chemical, and physiological - affect human thoughts, ideas, and judgments of value. This ignorance splits the realm of knowledge into two separate fields, the realm of external events, commonly called nature, and the realm of human thought and action. Reason and experience show us two separate realms: the external world of physical, chemical, and physiological phenomena, and the internal world of thought, feeling, valuation, and purposeful action. We have to stress the hard fact that the natural sciences have no intellectual tool to deal with ideas and with finality. Identical external events sometimes result in different human responses, and different external events sometimes produce the same human response. Consequently, a proposition of an aprioristic theory can never be refuted by experience. Human action always confronts experience as a complex phenomenon that first must be analyzed and interpreted by a theory, before it can even be set in the context of a hypothesis that could be proved or disproved. The a priori knowledge of praxeology is entirely different - categorially different from the a priori knowledge of mathematics or, more precisely, from mathematical a priori knowledge as interpreted by logical positivism. The starting point of all praxeological thinking is not arbitrarily chosen axioms, but a self-evident proposition, fully, clearly, and necessarily present in every human mind. The characteristic feature of man is precisely that he consciously acts. Man is Homo agens, the acting animal. To act means: to strive after ends; that is, to choose a goal and to resort to means in order to attain the goal sought.)

3. Judgments of value and subjectivism (Judgments of value are voluntaristic. While judgments of value are personal, subjective, and final, judgments about means are essentially inferences drawn from factual propositions concerning the power of the means in question to produce definite effects. With regard to judgments of value, there cannot be any question of truth and falsity. They are ultimate and not subject to any proof or evidence. For the science of human action, the valuations and goals of the final order at which men aim constitute the ultimate given, which it is unable to explain any further. Science can record and classify values, but it can no more "explain" them than it can prescribe the values that are to be acknowledged as correct or condemned as perverted. By means of its subjectivism the modern theory becomes the objective science. It does not pass judgment on action, but takes it exactly as it is; and it explains market phenomena not on the basis of "right" action, but on the basis of given action. The characteristic mark of ultimate ends is that they depend entirely on each individual's personal and subjective judgment, which cannot be examined, measured, or still less corrected by 
any other person. The significance of value judgments consists precisely in the fact that they are the springs of human action. Guided by his valuations, man is intent upon substituting conditions that please him better for conditions which he deems less satisfactory. He employs means to attain ends sought. Means are judged and appreciated according to their ability to produce definite effects. The characteristic feature of a free society is that it can function even though its members disagree in many judgments of value. In the market economy, business serves not only the majority but also various minorities, provided they are not too small in respect of the economic goods which satisfying their special wishes would require.)

4. Individualism (Each individual is the only and final arbiter in matters concerning his/her own satisfaction and happiness. The whole economy (and the whole development of civilization) is the result of what individuals do. The basis of social development is always individual activity, choosing, cooperation, competition, trading, etc. Economic phenomena (e.g. prices, wages, interest rates, money, monopoly) are outcomes of countless conscious, purposive actions, choices, and preferences of individuals, trying to attain various wants and ends and to avoid undesired consequences. Praxeology deals with the actions of individual men. It is true that man is always the member of a collective, but the study of the individual is posterior to the study of society. Nobody ventures to deny that nations, states, municipalities, parties, religious communities, are real factors determining the course of human events. Methodological individualism, far from contesting the significance of collective wholes, considers it as one of its main tasks to describe and to analyze their becoming and their disappearing, their changing structures, and their operation. A collective always operates through the intermediary of one or several individuals whose actions are related to the collective as the secondary source. The evolution of social institutions as, e.g., reason, language, and cooperation, is the outcome activity of individuals. The problems raised by the multiplicity of coexisting social units and their mutual antagonisms can be solved only by methodological individualism. The preservation of society is an essential condition of any plans an individual may want to realize by any action whatever. The market is a social body; market phenomena are social phenomena. They are the result of each individual's active contribution. The characteristic feature of a free society is that it can function even though its members disagree in many judgments of value. Individuals as consumers value goods exactly so much and no more or less at a given moment because of the operation of the social and 
natural forces that determine their lives. Means are judged and appreciated by each individual according to their ability to produce definite effects (ends).)

5. Rationalism and human action (The terms "reasoning" and "rationality" always refer only to the suitability of means chosen for attaining ultimate ends. The choice of ultimate ends is in this sense always irrational. It is not experience, but reason, which is prior to experience, that tells us what is a free and what is an economic good. If we were to attempt to distinguish rational action from irrational action, we should not only be setting ourselves up as a judge over the scales of the value of our fellow men, but we should also be declaring our own knowledge to be the only correct, objective standard of knowledge. The assertion that there is irrational action is always rooted in an evaluation of a scale of values different from our own. Whoever says that irrationality plays a role in human action is merely saying that his fellow men behave in a way that he does not consider correct. 'He acts irrationally' is meaningless, because it is not compatible with the concept of action. The 'seeking to attain an end' and the 'striving after a goal' cannot be eliminated from the concept of action.)

6. Consumer (The whole economic process is rooted and based on the sovereignty of the consumer. The captain is the consumer. Contrary to the almost common belief, understanding of economic processes does not start from the action of the businessman, but from that of the consumers, that is to say, from the action of everybody. In his capacity as a businessperson, a man is a servant of the consumers, bound to comply with their wishes. Customers' whims and fancies are, for the businessman or entrepreneur, the ultimate law, provided these customers are ready to pay for them. He is under the necessity of adjusting his conduct to the demand of the consumers. If consumers, without a taste for the beautiful, prefer things ugly and vulgar, a producer must, contrary to his own convictions, supply them with such things. Living and acting, man by necessity combines various functions. He is never merely a consumer. He is in addition either an entrepreneur, landowner, capitalist, or worker, or a person supported by the income earned by such people. Moreover, the functions of the entrepreneur, the landowner, the capitalist, and the worker are very often combined in the same persons. Consumers make poor people rich and rich people poor. They determine precisely what should be produced, in what quality, and in what quantities. The consumers determine ultimately not only the prices of consumer goods but no less the prices of all factors of production. They determine the income of every member of the market economy. Consumers, not the entrepreneurs, pay ultimately the 
wages earned by every worker, the glamorous movie star as well as the charwoman. It is necessary to realize that consumer sovereignty is not perfect and that there are limits to the operation of the democratic process of the market.)

7. Cooperation and competition (Social cooperation and social competition (rivalry) are two sides of the same coin. They are intertwined processes. Almost universal acceptance of social cooperation might be perceived as the result of natural phenomena, but it is hard to say that cooperation among individuals of a biological species is a universal natural phenomenon. At the level of civilization development, biological competition was replaced by social cooperation and peaceful social rivalry. What made social cooperation possible is, of course, a natural phenomenon - the higher productivity of labor accomplished under the principle of the division of labor and specialization of tasks. The problem is to organize society for the best possible realization of those ends, which men want to attain through social cooperation. Social utility is the only standard of justice.)

8. Thymology (Usually, the meaning of the term "psychology" is restricted to the field of experimental psychology, a discipline that resorts to the research methods of the natural sciences. To prevent mistakes resulting from the confusion of two entirely different branches of knowledge (i.e. natural and social sciences) Mises proposes to reserve the term "psychology" for naturalistic psychology and to call the knowledge of human valuation and volition "thymology". He describes it in chapter 12 in Theory and History (1985, pp. 264-284). Thymology is not related to praxeology and economics. The popular belief that modern subjective economics, the marginal utility school, is founded on or closely connected with "psychology" is mistaken. The very act of valuing is a thymological phenomenon. But praxeology and economics do not deal with the thymological aspects of valuation. Psychology in the sense of thymology is a branch of history. It derives its knowledge from historical experience. The thymological observation both of other people's choices and of the observer's own choosing necessarily always refers to the past, in the way that historical experience does. There is no method available which would produce in this field something analogous to what the natural sciences consider an experimentally established fact. Thymological experience is what we know about human value judgments, the actions determined by them, and the responses these actions arouse in other people. This experience stems either from introspection or from intercourse with other men, from our acting in various interhuman relations. We must take recourse to thymology if we want to anticipate other people's future attitudes and actions. Out of our general thymologi- 


\section{Witold Kwasnicki}

cal experience, acquired either directly from observing our fellow men and transacting business with them or indirectly from reading and from hearsay, as well as out of our special experience acquired in previous contacts with the individuals or groups concerned, we try to form an opinion about their future conduct. It is easy to see in what the fundamental difference consists between this kind of anticipation and that of an engineer designing a plan for the construction of a bridge. Thymology tells no more than that man is driven by various innate instincts, various passions, and various ideas. The anticipating individual tries to set aside those factors that manifestly do not play any role in the concrete case under consideration. Thymology deals with the mental activities of men that determine their actions. It deals with the mental processes that result in a definite kind of behavior, with the reactions of the mind to the conditions of the individual's environment. It deals with something invisible and intangible that cannot be perceived by the methods of the natural sciences. Nevertheless, the natural sciences must admit that this factor must be considered as real also from their point of view, as it is a link in a chain of events that result in changes in the sphere the description of which they consider as the specific field of their studies.)

9. Mathematics in economics (The fundamental difference between the natural sciences and the sciences of human action (e.g. economics) is that in the world of nature constant relations exist between various elements and in the sciences of human action no such constant relations exist. Therefore, a natural scientist is able to use measurements and quantitative description, which allows the building of formal mathematical models of the real world. Contrary, in human action research no measurement and no quantification are possible. All measurable magnitudes that the sciences of human action encounter are quantities of the environment in which man lives and acts. Those theorists who are usually designated as the great masters of mathematical economics accomplished what they did without mathematics. Only afterwards did they seek to present their ideas in mathematical form. This is because physics is able to discover empirically constant relationships, which it describes in its equations. Thus far, the use of mathematical formulations in economics has done more harm than good. Of primary importance is what is set forth in words in the preliminary statement that has to serve as the starting point for further mathematical elaboration. This statement, however, is always nonmathematical. Whether or not its further elaboration in mathematical terms can be used depends on the correctness of this initial nonmathematical statement. Mathematics has a significance in the natural sciences altogether dif- 
ferent from what it has in sociology and economics. It is not a shortcoming of the sciences of human action that they have not succeeded in discovering determinate stimulus-response patterns. What does not exist cannot be discovered. There is no such thing as statistical laws. People resort to the methods of statistics precisely where they are not in a position to find regularity in the concatenation and succession of events. As a method of economic analysis, econometrics is a childish play with figures that does not contribute anything to the elucidation of the problems of economic reality.)

10. Predictions (It is true that no action can be planned and proceeded without an understanding of the future. Even an action of an isolated individual is guided by definite assumptions about the actor's future value judgments and is so far determined by the actor's image of his own character. The term "speculate" was originally employed to signify any kind of meditation and forming of an opinion. In modern times it is employed with an opprobrious connotation to disparage those men (entrepreneurs) who, in the capitalistic market economy, excel in better anticipating the future reactions of their fellow men than the average man does. Although even in economics predictions can be made in the sense in which this ability is attributed to the natural sciences, we ought to remember that the concrete value judgments of individuals appear only as data. We must emphasize that the probability of any prognoses concerning future human action has little in common with that category of probability which is dealt with in the mathematical calculus of probability. The former is case probability and not class probability. In order to prevent confusion, it is advisable to refer to case probability as likelihood. Nobody is in a position to predict with the same assurance with which the natural sciences make predictions how he himself and other people will act in the future. There is no method that would enable us to learn about a human personality all that would be needed to make such prognostications with the degree of certainty technology attained in its predictions. The predictions of praxeology are, within the range of their applicability, absolutely certain. But they do not tell us anything about the value judgments of the acting individuals and the way they will determine their actions. Economics can predict the effects to be expected from resorting to definite measures of economic policies. It can answer the question whether a definite policy is able to attain the ends aimed at and, if the answer is in the negative, what its real effects will be. But, of course, this prediction can be only "qualitative." It cannot be "quantitative" as there are no constant relations between the factors and effects concerned.) 
11. Historical analysis (There are two branches of the sciences of human action, praxeology and history. Praxeology (economics) starts from a priori category of action and develops out of it all that it contains. History in the broadest sense of the term is the totality of human experience. History is experience, and all experience is historical. Experience is always an experience of the past. The historian cannot duplicate or reproduce the past; on the contrary, he interprets and recasts it, and this requires that he make use of some ideas that he must have already had before setting about his work. What distinguishes descriptions of history from those of the natural sciences is that they are not interpreted in the light of the category of regularity. Even if, in the course of a historian's work, the treatment of material leads to new ideas, concepts are always logically prior to the understanding of the individual, the unique, and the non-repeatable. However, what we know about our action under given conditions is derived not from experience, but from reason. History cannot be imagined without theory. The naive belief that, unprejudiced by any theory one can derive history directly from the sources, is quite untenable. History must be repeatedly rewritten because the subjective element in the passing of time and the change in personalities, again and again, opens up new vistas for understanding. Both theory and history are equally legitimate, and both are equally indispensable. The virtue of historical inquiry does not lie in the derivation of laws. Its cognitive value is not to be sought in the possibility of its providing direct practical applications for our action. It deals only with the past; it can never turn toward the future. History makes one wise, but not competent to solve concrete problems. The antagonism between economics and historicism does not concern historical facts. It involves the interpretation of the facts. In investigating and narrating facts a scholar may provide a valuable contribution to history, but he does not contribute to the increase and perfection of economic knowledge. History is the record of human action. Ideas are the main theme of the study of history. Ideas are not an invariable stock that existed from the very beginning of things, and that does not change. Every idea originated at a definite point in time and space in the head of an individual. History deals with values, but it itself does not value. It looks at events with the eyes of an unaffected observer. This is, of course, the characteristic mark of objective thought and of the scientific search for truth. The historian can never derive theorems about cause and effect from the analysis of the material available. Historical experience is not laboratory experience. It is an experience of complex phenomena, of the outcome of the joint operation of various forces). 


\section{Rationalism}

I am not able to deal here with all dimensions of Mises's legacy, therefore I will select only one dimension, namely rationality. The concept of rationality proposed by Ludwig von Mises is so neglected by modern researchers that it is worth presenting and discussing. I was surprised and highly disappointed that I found no mention of Ludwig von Mises's concept of rationality in such well-known books as:

- Hollis Martin, Edward J. Nell, Rational Economic Man A Philosophical Critique of Neo Classical Economics, Cambridge University Press (1975). ${ }^{3}$

- Robert E. Lucas Jr., Thomas J. Sargent, Rational Expectations and Econometric Practice Volume 1, University of Minnesota Press (1981).

- Robert E. Lucas Jr., Thomas J. Sargent, Rational Expectations and Econometric Practice Volume 2, University of Minnesota Press (1982).

- Rogers Brubaker, The Limits of Rationality An Essay on the Social and Moral Thought of Max Weber, Routledge (1988).

- Richard H. Thaler, Quasi Rational Economics, Russell Sage Foundation (1991).

- Wolfgang Schluchter, The Rise of Western Rationalism Max Weber's Developmental History, University of California Press (1992).

- Stefan Amsterdamski, Between History and Method Disputes about the Rationality of Science, Springer Netherlands (1992).

- Gerard Radnitzky and W. W. Bartley, III, eds, Evolutionary Epistemology, Rationality, and the Sociology of Knowledge (with contributions by Sir Karl Popper, Donald T. Campbell, W. W. Bartley, III, Giinter Wachtershauser, Rosaria Egidi, Gerhard Vollmer, John F. Post, John Watkins, Gerard Radnitzky, Peter Munz, and Antony Flew), Open Court (1993).

- Uskali Maki, Bo Gustafsson, Christian Knudsen (eds), Rationality, Institutions and Economic Methodology, Routledge (1993). ${ }^{4}$

- Gerd Gigerenzer, Adaptive Thinking Rationality in the Real World, Oxford University Press, Inc. (2000).

- Gerd Gigerenzer, Reinhard Selten, Bounded Rationality The Adaptive Toolbox, MIT Press (2002).

- Vernon L. Smith, Rationality in Economics, Constructivist and Ecological Forms, Cambridge University Press (2007).

- Gerd Gigerenzer, Rationality for Mortals How People Cope with Uncertainty Evolution and Cognition, Oxford University Press, Inc. (2008). 
- Tim Harford, The Logic of Life The Rational Economics of an Irrational World, The Random House Publishing Group (2008).

- Ken Binmore, Rational Decisions, Princeton University Press (2009). ${ }^{5}$

- Peter M. Todd, Gerd Gigerenzer and the ABC Research Group, Ecological Rationality, Intelligence in the World, Oxford University Press, Inc. (2012).

- Maurizio Catino, Organizational Myopia Problems of Rationality and Foresight in Organizations, Cambridge University Press (2013).

- Nassim Nicholas Taleb, Skin in the Game, Hidden Asymmetries in Daily Life, Random House (2018).

The title of the highly estimated book by Vernon L. Smith (2007) suggests that the author aimed to present the review of the concept of 'rationality in economics'. The monograph covers the wide range of concepts on rationality. V.L. Smith (2007, p. 2) admits in the introduction that he will refer to F. A. Hayek's important distinction between two kinds of rationality and that he will try to "relate all of this book's discussion and examples - experimental, field empirical, descriptive - to the following two concepts of rationality" namely Constructivist rationality, and Ecological rationality. Constructivist rationality involves the deliberate use of reason to analyze and prescribe actions judged to be better than feasible alternative actions that might be chosen. When applied to institutions, constructivism involves the deliberate design of rule systems to achieve desirable performance. Ecological rationality refers to the emergent order in the form of the practices, norms, and evolving institutional rules governing action by individuals that are part of our cultural and biological heritage and are created by human interactions, but not by conscious human design. The two concepts are not inherently in opposition. In the opinion of Vernon Smith, the issues are emphatically not about constructivist versus ecological rationality, as some might infer or prefer, and the two can and do work together. For example, in evolutionary processes, constructivist cultural innovations can provide variations while ecological fitness processes do the work of selection. Unfortunately, Vernon Smith is not referring to the work of Ludwig von Mises, Hayek's mentor and teacher.

\section{What is rationalism and irrationalism?}

Mises in his early considerations on rationalism, made in the 1930s, hits the point, that to "distinguish rational action from irrational action, we should not only be setting ourselves up as a judge over the scales of value of our fellow men, but we should also be declaring our own knowledge to 
be the only correct, objective standard of knowledge" (Mises, 2003/1933, p. 35).

Anybody's claiming that some action is irrational, means that his/her scale of values is different from that person 'behaving irrationally'. Saying that some action is irrational is expressing the opinion that this behavior is considered as incorrect. If we do not wish to make a judgment related to the ends and the scales of value of other people and do not claim omniscience for ourselves, considering some action as irrational is meaningless, simply because it is not compatible with the concept of action. Therefore, the 'concepts rational and irrational are not applicable to ends at all'. However, the expressions "rational" and "irrational" may be applied to the means employed for the attainment of an end. The use of means other than those considered from a given technological point of view as "rational" might be related to a situation that the "rational" means were not known to the actor, or that they are not employed because somebody wishes to attain other ends. In both cases, there is no justification to say that the action is 'irrational'.

For Mises (Mises, 2003/1933, p. 36): "Action is, by definition, always rational'. 'Instead of saying that irrationality plays a role in the action, we should accustom ourselves to saying merely: There are people who aim at different ends from those that I aim at, and people who employ different means from those I would employ in their situation' (Mises, 2003/1933, p. $36-7)$.

The concept of rationalism might be considered as correct in the case of almost commonly accepted ultimate ends such as preservation of life and health. Extending it to all ends leads to incorrect findings and suggestions. The assumption that all men are endowed with the same power of reasoning leads to omitting differences in cleverness of people. This leads to incorrect claims that once all people have had a perfect education, all will be 'as wise and judicious as the most eminent sage'. Rationalism also neglects the problem of erroneous thinking. Usually, rationalist philosophers do not accept the situation that 'even honest men, sincerely devoted to the search for truth, could err' (Mises, 1985/1957, 269-70).

All human phenomena are dynamic processes and we ought to consider them as immersed in the passing time. This is forgotten in the case of attaining the notion of an irrational action by logical reasoning. Usually, it is said that: 'If $a$ is preferred to $b$ and $b$ to $c$, logically $a$ should be preferred to $c^{\prime}$. That is considered as rational behavior, and claiming that $\mathrm{c}$ is preferred to $a$ is considered as irrational. These might look quite different if we apply the category of time into our considerations. Preferring ' $a$ to $b$ ' and ' $b$ to $c$ ' 


\section{Witold Kwasnicki}

are never synchronous decisions. Usually something internal exists between those decisions. It is not permissible to assume that within that interval the scale of value was constant and value judgments were not influenced by external or internal events. "Value judgments are not immutable and that therefore a scale of value, which is abstracted from various, necessarily nonsynchronous actions of an individual, may be self-contradictory" (Mises, 1963/1949, p. 103; Mises, 1985/1957, p. 281-2).

Another problem discussed by Mises is differences in the notions of constancy and rationality. If for some reason(s) one's valuations have changed, clinging to the once selected principles of action "just for the sake of constancy would not be rational but simply stubborn'. There is only one case of the constant action of a human being: "in preferring the more valuable to the less valuable". Clinging to old behavior, under changed conditions, would be nonsensical. "A logical system must be consistent and free of contradictions because it implies the coexistence of all its parts and theorems. In acting, which is necessarily in the temporal order, there cannot be any question of such consistency. Acting must be suited to purpose, and purposefulness requires adjustment to changing conditions" (Mises, 1963/1949, p. 103).

\section{Means and ends - rationalization}

Judgments on the suitability, appropriateness, and adequacy of the procedure applied to the means chosen for the attainment of ends might be considered as rational or irrational. Intentions based on human reasoning are not infallible, and a man very often errs in selecting and applying means. The employed means might be inefficient or inadequate in the process of achieving the ends but still ought to be considered rational. As Mises (1963/1949, 20) writes: "The doctors who a hundred years ago employed certain methods for the treatment of cancer which our contemporary doctors reject were - from the point of view of present-day pathology - badly instructed and therefore inefficient. But they did not act irrationally; they did their best. It is probable that in a hundred years more doctors will have more efficient methods at hand for the treatment of this disease. They will be more efficient but not more rational than our physicians".

Very frequently, we hear opinions that it is irrational to attain 'ideal or 'higher' goals instead of searching for 'material' and tangible ends. In the same mood, it is claimed that a man who sacrifices life, health, or wealth to the attainment of 'higher goals' (religious, philosophical) is motivated by irrational considerations. "However, the striving after these higher ends is neither more nor less rational or irrational than that after other human ends. It is a mistake to assume that the desire to procure the bare necessities of 
life and health is more rational, natural, or justified than the striving after other goods or amenities. It is true that the appetite for food and warmth is common to men and other mammals and that as a rule a man who lacks food and shelter concentrates his efforts upon the satisfaction of these urgent needs and does not care much for other things. The impulse to live, to preserve one's own life, and to take advantage of every opportunity of strengthening one's vital forces is a primal feature of life, present in every living being. However, to yield to this impulse is not - for man - an inevitable necessity" (Mises, 1963/1949, p. 19).

When we think of a man as a rational being, we ought to take into consideration also his biological constitution. It is true that his/her behavior is governed by impulsive reactions, but "rational conduct means that man, in face of the fact that he cannot satisfy all his impulses, desires, and appetites, foregoes the satisfaction of those which he considers less urgent. In order not to endanger the working of social cooperation man is forced to abstain from satisfying those desires whose satisfaction would hinder the establishment of societal institutions. There is no doubt that such a renunciation is painful. However, man has made his choice. He has renounced the satisfaction of some desires incompatible with social life and has given priority to the satisfaction of those desires which can be realized only or in a more plentiful way under a system of the division of labor. He has entered upon the way toward civilization, social cooperation, and wealth" (Mises, 1963/1949, p. 172).

\section{Rationalism and individualism}

We ought to accept that "a doctrine that rejects rationalism, individualism, and eudaemonism can say nothing about human action" (Mises, Mises, 2003/1933, p. 60). That rejection leads to an awkward perception of humanity and leads to stopping at the enumeration and description of a number of instincts and elaborations "that men love and hate, that they are garrulous and taciturn, that they are cruel and compassionate, that they are sociable and that they shun society". However, the essence of human beings is omitted, namely that they act, work, cooperate, and labor to achieve goals, their individual ends. The action is strictly associated with individualism and rationality. The goal of an individual's action is the removal of dissatisfaction. "If one wants to explain society without reference to the actions of men, the only expedient that remains is to view it as the outcome of mysteriously operating forces. Society is then the result of the instinct of association; it is "inner communion"; it is basic and intrinsic; it is not of this world" (Mises, 2003/1933, p. 60). 


\section{Rationalism, economic action and homo economicus}

The subjective theory of value imposes a precise separation between the "economic" and the "noneconomic" factors. The economic principle is the fundamental principle of all rational action, and therefore we can say that all rational action is an act of economizing. Just to repeat what was already said: 'every conscious, i.e., meaningful, action is rational'. The ultimate values and ends (at which action aims) are beyond rationality. Therefore, it is not permissible "to contrast 'correct' action as 'rational' to 'incorrect' action, i.e., action diverted through misunderstanding ignorance, or negligence from employing the best means available to attain the ends sought. Nor was it henceforth possible to call an action irrational in which values like honor, piety, or political goals are taken into consideration" (Mises, 2003/1933, p. 157).

The personification of the principles of the businessman in the classical theory is the concept of homo economicus. The businessman wants to conduct every business to increase profit, just to attain the highest possible profit. Through strenuousness and solicitude the businessman endeavors to eliminate all sources of error so that the results of his/her action are 'not prejudiced by ignorance, neglectfulness, mistakes, and the like'. Contrary to most common belief classical economics did not assert that the economizing individual, either a producer or a consumer, acts as if the greatest monetary profit were the sole guiding principle of his/her conduct. "The principle of buying on the cheapest market comes into question here only in so far as the choice is between several possibilities, otherwise equal, of purchasing goods; but it cannot be understood, from this point of view, why someone buys the better suit even though the cheaper one has the same "objective" usefulness, or why more is generally spent than is necessary for the minimum - taken in the strictest sense of the term - necessary for bare physical subsistence. It did not escape even the classical economists that the economizing individual as a party engaged in trade does not always and cannot always remain true to the principles governing the businessman, that he is not omniscient, that he can err, and that, under certain conditions, he even prefers his comfort to a profit-making business" (Mises, 2003/1933, p. 191). Mises notes that the scheme of the homo economicus in classical economics grasps only one side of man - the materialistic side. Besides treating him as a man engaged in business, we ought to treat him also as a consumer of economic goods.

Mises made a comment on rationality in Theory and history in a similar mood: "the fundamental thesis of rationalism is unassailable. Man is a rational being; that is, his actions are guided by reason. The proposition: Man acts, is tantamount to the proposition: Man is eager to substitute a state of 
affairs that suits him better for a state of affairs that suits him less. In order to achieve this, he must employ suitable means. It is his reason that enables him to find out what is a suitable means for attaining his chosen end and what is not" (Mises, 1985/1957, p. 269). That opinion can be treated as the continuation of his earlier view expressed in his magnum opus in 1949 that "Human action is necessarily always rational. The term "rational action" is therefore pleonastic and must be rejected as such. When applied to the ultimate ends of action, the terms rational and irrational are inappropriate and meaningless. The ultimate end of action is always the satisfaction of some desires of the acting man. Since nobody is in a position to substitute his own value judgments for those of the acting individual, it is vain to pass judgment on other people's aims and volitions. No man is qualified to declare what would make another man happier or less discontented. The critic either tells us what he believes he would aim at if he were in the place of his fellow; or, in dictatorial arrogance blithely disposing of his fellow's will and aspirations, declares what condition of this other man would better suit himself, the critic" (Mises, 1963/1949, p. 19).

\section{Rationalism and 'primitive' societies}

Rational behavior is present not only in modern civilization. People of past societies, those a few centuries ago as well as so-called primitive societies thousands of years ago, were no less rational than so-called 'modern men'. Ethnological research shows clearly that the reasoning of so-called primitive peoples leads to different findings and conclusions from those of reasoning made by modern man but it does not mean that the "primitive man' was less rationalistic than the modern one. "When primitive man assumes magical and mystical connections where we assume connections of a different kind, or where we find no connection at all, or when he sees no connection where we do see one, this shows only that the content of his reasoning differs from that of our own, but not that his reasoning is of a different logical structure from ours" (Mises, 2003/1933, p. 112).

Making errors and mistakes are frequently tied to irrational behavior. Making errors and mistakes is the natural weakness of a human being. "Some err less often than others, but no mortal man is omniscient and infallible. Error, inefficiency, and failure must not be confused with irrationality. He who shoots wants, as a rule, to hit the mark. If he misses it, he is not "irrational"; he is a poor marksman. The doctor who chooses the wrong method to treat a patient is not irrational; he may be an incompetent physician. The farmer who in earlier ages tried to increase his crop by resorting to magic rites acted no less rationally than the modern farmer who applies more fer- 
tilizer. He did what according to his - erroneous - opinion was appropriate to his purpose" (Mises, 1985/1957, p. 268).

Our thinking about the past and on the development of old societies seems to be specifically biased. Very frequently we are tempted to underestimate the achievements of past societies and old civilizations. Eagerly we call their behavior inefficient, irrational, or even stupid; all contrary to high efficacy, the very rational wisdom of modern man, of modern 'advanced societies'. (see Mises, 1985/1957, p. 280-1).

\section{Science and rationalism}

Mises clearly states: "Science belongs completely to the domain of rationality" (e.g., Mises, 2003/1933, p. 143). In this respect, there is no difference between the natural sciences and the social sciences. "Science is the endeavor to attain a mental grasp of the phenomena of the universe by a systematic arrangement of the whole body of available knowledge. The human mind is not even capable of conceiving a kind of knowledge not limited by an ultimate given inaccessible to further analysis and reduction. The scientific method that carries the mind up to this point is entirely rational. The ultimate given may be called an irrational fact" (Mises, 1963/1949, p. 21). Therefore economic theory, as a social science, "is rationalistic in the sense that it makes use of the methods of reason - ratio" (Mises, 2003/1933, p. 98). "Like every branch of knowledge economics goes as far as it can be carried by rational methods. Then it stops by establishing the fact that it is faced with an ultimate given, i.e., a phenomenon which cannot - at least in the present state of our knowledge - be further analyzed" (Mises, 1963/1949, p. 21).

In particular, "liberalism is based upon a purely rational and scientific theory of social cooperation. The policies it recommends are the application of a system of knowledge which does not refer in any way to sentiments, intuitive creeds for which no logically sufficient proof can be provided, mystical experiences, and the personal awareness of superhuman phenomena. In this sense the often misunderstood and erroneously interpreted epithets atheistic and agnostic can be attributed to it" (Mises, 1963/1949, p. 155).

\section{Conclusions}

Taleb is prying open the door

The latest book by Nassim Taleb, Skin in the Game: Hidden Asymmetries in Daily Life, (published in February 2018) is the continuation of his saga on uncertainty (four volumes published separately from 2001 to 2012 
was republished together as Incerto in 2016). Taleb $(2018,441,9)$, in the Misesian mood, says: "skin in the game means that you do not pay attention to what people say, only to what they do". On his blog he makes it more precise: "Skin in the game - as a filter - is the central pillar for the organic functioning of systems, whether humans or natural. Unless consequential decisions are taken by people who pay for the consequences, the world would be vulnerable to total systemic collapse" 6 .

I refer to Taleb's book because a large part of that volume deals with rationality. Taleb argues that only when people are exposed to the adverse consequences of their decisions are they eager to take risks that are positive for society. When they do not have "skin in the game," they take risky decisions, which are usually harmful and dangerous for the society. This is not the place to review Taleb's new book, but it is worth noting that the book corresponds heavily with libertarian ideas based on 'respect for private property, liberty and freedom, responsibility and mutual trust'. The same may be said about his concept of rationality. His ideas fully correspond to what was said by Ludwig von Mises, but what is annoying, he does not refer to Mises's work at all. No single word on Mises's ideas!

As Taleb $(2018,10,8)$ writes: "Rationality in the real world isn't about what makes sense to your New Yorker journalist or some psychologist using naive first-order models, but something vastly deeper and statistical, linked to your own survival". ${ }^{7}$

How Misesian his opinion about irrationality and rationality sounds: "we know what is patently irrational: what threatens the survival of the collective first, the individual second. ... By definition, what works cannot be irrational; about every single person I know who has chronically failed in business shares that mental block, the failure to realize that if something stupid works (and makes money), it cannot be stupid' (Taleb, 2018, 56,3).

Taleb states in a few places in his book that 'What is rational is what allows the collective - entities meant to live for a long time - to survive. What is rational is that which allows for survival. Rationality is avoidance of systemic ruin'. Similar to Mises, he claims that "there is no rigorous definition of rationality that is not related to skin in the game; it is all about actions, not verbs, thoughts, and tawk".

Like Mises, Taleb states, on the importance of human action, that "skin in the game means that you do not pay attention to what people say, only to what they do, and to how much of their necks they are putting on the line. Let survival work its wonders" (Taleb, 2018, 441,4), and "we do not 
have enough grounds to discuss "irrational beliefs". We do with irrational actions" (Taleb, 2018, 444,7), as well as: "Anything that hinders one's survival at an individual, collective, tribal, or general level is, to me, irrational' (Taleb 2018, 446,9).

Taleb summarizes his considerations in the Misesian spirit: "Rationality does not depend on explicit verbalistic explanatory factors; it is only what aids survival, what avoids ruin. ... Not everything that happens happens for a reason, but everything that survives survives for a reason" (Taleb, $2018,448,0)$.

I would like to conclude with an attempt at definition inspired by Mises: Rationality (rational behavior) is associated with the action of an individual aiming at reaching subjective ends by choosing proper and rare means. The choosing is based on currently available knowledge and understanding of the universe. The important feature of the rationality is that the individual can learn from his/her errors as well as successes. The learning process is the essence of the rational behavior.

\section{N O T E S}

1 Theory and History was the first book of Mises read by me. It was at the beginning of the 1980s, during martial law in communist Poland (where I was born and living). It was not common to find books by such 'bourgeois' authors in Poland durig the communist period, and I do not know why the book of Mises was available in the library of my university. I remember that the book bewildered me. Later on I read his other books, and currently, I proudly may say that I am a Misesian (Austrian) economist.

2 Although Theory and History might and, in my opinion, ought to be read by the general reader interested in economic problems.

3 There is only one passage with reference to Mises's work on monetary theory, here we read: "The one emphasised in 1932 is in the spirit of von Mises's remark that 'in the concept of money all the theorems of monetary theory are already implied"".

${ }^{4}$ In the chapter on 'Economic methodology, Rationale, Foundations, Prospects, by Bruce J.Caldwell p. 55: "Disconfirmation can be avoided completely by dropping the requirement of a well defined preference function, thereby emptying the assumption of any empirical content. This is the route taken by Mises (1949), who claimed that preferences are revealed in the act of choice. Apparent inconsistencies are always attributable to changes in subjective preferences; all human action is by definition rational."

${ }^{5}$ I found here only one remark: "Richard von Mises was the younger brother of Ludwig von Mises, who is still honored as a leading member of the Austrian school of economics. However, Richard's espousal of the logical positivism of the Vienna circle put him at the opposite end of the philosophical spectrum to his brother".

6 https://medium.com/incerto/what-do-i-mean-by-skin-in-the-game-my-own-version-cc $858 \mathrm{dc} 73260$

7 At the beginning of his book Taleb $(2018,434,9)$ warns: "A statement that will orient us for the rest of the book: Survival comes first, truth, understanding, and science later". 


\section{R E F E R E N C E S}

Amsterdamski Stefan, Between History and Method Disputes about the Rationality of Science, Springer Netherlands (1992).

Binmore Ken, Rational Decisions, Princeton University Press (2009).

Brubaker Rogers, The Limits of Rationality An Essay on the Social and Moral Thought of Max Weber, Routledge (1988).

Catino Maurizio, Organizational Myopia Problems of Rationality and Foresight in Organizations, Cambridge University Press (2013).

Frederick Danny, "Two Concepts of Rationality," Libertarian Papers 2, 5 (2010). Online at: libertarianpapers.org.

Gigerenzer Gerd, Rationality for Mortals How People Cope with Uncertainty Evolution and Cognition, Oxford University Press, Inc. (2008).

Gigerenzer Gerd, Adaptive Thinking Rationality in the Real World, Oxford University Press, Inc. (2000).

Gigerenzer Gerd, Reinhard Selten, Bounded Rationality The Adaptive Toolbox, MIT Press (2002).

Harford Tim, The Logic of Life The Rational Economics of an Irrational World, The Random House Publishing Group (2008).

Hollis Martin, Edward J. Nell, Rational Economic Man A Philosophical Critique of Neo Classical Economics, Cambridge University Press (1975).

Lange Oskar (1936), 'On the Economic Theory of Socialism, Part One', Review of Economic Studies, 4(1), pp. 53-71.

Lange Oskar (1937), 'On the Economic Theory of Socialism, Part Two', Review of Economic Studies, 4(2), pp. 123-142.

Lucas Robert E. Jr., Thomas J. Sargent, Rational Expectations and Econometric Practice Volume 1, University of Minnesota Press (1981).

Lucas Robert E. Jr., Thomas J. Sargent, Rational Expectations and Econometric Practice Volume 2, University of Minnesota Press (1982).

Maki Uskali, Bo Gustafsson, Christian Knudsen (eds), Rationality, Institutions and Economic Methodology, Routledge (1993).

Mises Ludvig von (1962), The Ultimate Foundation of Economic Science: An Essay on Method, New York: D. Van Nostrand Company, LTD.

Mises Ludvig von (1963/1949), Human Action: A Treatise on Economics, San Francisco: Fox \& Wilkes.

Mises Ludvig von (1985/1957), Theory and History: An Interpretation of Social and Economic Evolution, Auburn: Ludwig von Mises Institute.

Mises Ludvig von (2003/1933), Epistemological Problems of Economics, (org. Grundprobleme der Nationalökonomie: Untersuchungen über Verfahren, Aufgaben und Inhalt der Wirtschafts- und Gesellschaftslehre (1933)), Translated from the German by George Reisman, Published simultaneously in the 
United States and Canada by D. Van Nostrand Co., 1960 (Third edition 2003 by Ludwig von Mises Institute).

Nassim Nicholas Taleb, Skin in the Game, Hidden Asymmetries in Daily Life, Random House (2018).

Radnitzky Gerard and W. W. Bartley, III, eds, Evolutionary Epistemology, Rationality, and the Sociology of Knowledge (with contributions by Sir Karl Popper, Donald T. Campbell, W. W. Bartley, III, Giinter Wachtershauser, Rosaria Egidi, Gerhard Vollmer, John F. Post, John Watkins, Gerard Radnitzky, Peter Munz, and Antony Flew), Open Court (1993).

Rothbard, Murray N. (1975). Reviews of Ludwig von Mises, Omnipotent Government and Theory and History. Libertarian Review, June 1975, p. 1; https://www.libertarianism.org/publications/essays/mises omnipotent government theory history

Schluchter Wolfgang, The Rise of Western Rationalism Max Weber's Developmental History, University of California Press (1992).

Sieroń Arkadiusz, 'The Problem with Prescriptive "Rationality" in Economics', https://mises.org/wire/problem-prescriptive-rationality-economics, (2018).

Smith Vernon L. (2007), Rationality in Economics, Constructivist and Ecological Forms, Cambridge University Press (2007).

- Smith Vernon L., Rationality in Economics, Constructivist and Ecological Forms, Cambridge University Press (2007).

Taleb Nassim Nicholas (2018), Skin in the Game: Hidden Asymmetries in Daily Life, Random House (EPUB version).

Thaler Richard H., Quasi Rational Economics, Russell Sage Foundation (1991).

Todd Peter M., Gerd Gigerenzer and the ABC Research Group, Ecological Rationality, Intelligence in the World, Oxford University Press, Inc. (2012). 